\title{
THE UNFINISHED PAPER - A TRIBUTE TO GORDON ANDERSON
}

\section{KD Ewing*}

This article revisits arguments about the death of labour law, and re-examines claims by Richard
Mitchell that such arguments are mistaken. In the first half of the article I argue that the law of the
labour market is not labour law as the latter discipline developed in the 20th century. I also argue
that there is a clear ethical core to labour law which sets it apart from the law of the labour market,
and that this ethical core is the consequence of political struggle. Labour law gives effect to the
principle of international law that labour is not a commodity, a principle which the law of the labour
market subverts. The purpose of revisiting this debate is to examine whether labour law as so
understood can be resurrected. For this purpose, I focus on the recent work of Harry Arthurs who in
a series of lectures and elsewhere provides a withering assessment of the current state of play and a
bleak outlook for the future. While I agree strongly with his assessment of the current condition of the
discipline, I take issue with his pessimistic vision of the future, which in my view underestimates the
importance of political struggle in effecting social, economic and legal change. $\boldsymbol{I}$

In this article I would like to revisit a piece I wrote in 1988 in which I suggested that labour law was in terminal decline, and to consider whether the patient can recover. ${ }^{1}$ I address this question inspired by several conversations I had with Gordon when he was an academic visitor at King's College London in 2016. The plan had been for us to write a paper jointly in which we would reply to some of the negative, bleak and sombre assessments of the state of the discipline. The leading exponent of this genre in recent years has been Harry Arthurs who has offered an unremittingly dystopian analysis of labour law in an era of globalisation. As it is, we never managed to get past the stage of discussion. So, inspired by those discussions, I offer this article in tribute to Gordon, as the first draft of my half of the paper we had planned to write, confident in the knowledge that Gordon will disagree with much of what follows, but hopeful that he will want to complete it by providing the necessary corrections.

* Professor of Public Law, King's College, London.

1 Keith Ewing "The Death of Labour Law?" (1988) 8 OJLS 293. 
It is perhaps curious that I should locate my response to the contemporary dystopian school of labour law in an extended book review that 30 years ago predicted The Death of Labour Law, raising concerns that others have addressed in slightly less dramatic ways. ${ }^{2}$ It is perhaps even more curious that this response should be made in these circumstances without any admission of mea culpa on my part. And it is perhaps all the more curious still that the death of labour law thesis should be reassessed at a time of an ever expanding corpus of employment legislation and litigation throughout the world, and at a time of an ever expanding range of methods designed to give effect to labour standards. These include the hard law provisions of international human rights instruments, ${ }^{3}$ the regulatory initiatives of transnational organisations such as the European Union (EU), ${ }^{4}$ the expansion of constitutional law as a source of labour rights, ${ }^{5}$ the embedding of labour standards in free trade agreements, ${ }^{6}$ as well as soft law initiatives such as the OECD Guidelines for Multinational Enterprises. ${ }^{7}$

II

In the piece I wrote in 1988 I lamented the impact of Thatcherism on labour law, writing that: ${ }^{8}$

Whether labour law will have a positive role to play in shaping workers' lives in the future, may depend on whether the Labour Party holds political office again. It is now an inescapable fact of life in this country that labour law as a force for good is tied to the principles of democratic socialism. If democratic socialism perishes, then so will labour law. Yet it has to be said that for labour law the future is bleak. Affiliated membership of the TUC has fallen from its peak of 12.1 million in 1979 to 9.6 million in 1985, a fall of 20 per cent in six years. By all accounts the decline continues as the primary sector of the economy contracts. Trade unionism is being increasingly marginalized with the fall in manufacturing industry and the rise of the secondary labour market. The legal framework denies it the opportunity for growth and weakens its ability to resist. The vulnerability of the unions has implications for the Labour Party which

2 Compare Cynethia L Estlund "The Ossification of American Labor Law" (2002) 102 Colum L Rev 1527.

3 As a result, for example of the expanding jurisprudence of the European Convention on Human Rights, which is stretching into the workplace through arts 4 (slavery, servitude and forced labour); 8 (privacy, including privacy at and in relation to work); 10 (freedom of expression); and 11 (freedom of association and assembly).

4 Though these have been in retreat since 2010.

5 See Mounted Police Association of Ontario v Canada (Attorney-General) [2015] SCC 1, [2015] 1 SCR 3; and Saskatchewan Federation of Labour v Saskatchewan [2015] SCC 4, [2015] 1 SCR 245. Compare Board of Bendigo Regional Institute of Technical and Further Education v Barclay [No 2] [2012] HCA 42, (2012) 248 CLR 549.

6 See Joo-Cheong Tham and KD Ewing "Labour Clauses in the TTP and TTIP - A Comparison without a Difference?" (2016) 17 MJIL 369.

7 See Jill Murray "A New Phase in the Regulation of Multinational Enterprises: The Role of the OECD" (2001) 30 ILJ 255. The OECD Guidelines for Multinational Enterprises have been revised further since Murray's article, and work more effectively in some jurisdictions than others.

8 Ewing, above $\mathrm{n} 1$, at 299. 
has now lost its third successive election with its proportion of the popular vote falling by almost one-half in less than 30 years. If the unions continue to decline in an unfriendly economic and legal environment, the income base of the Labour Party will also continue to decline. Starved of funds, the Labour Party is in no position to recapture power. Without the Party in power the decline of trade unions and of labour law is unlikely to be halted, never mind reversed.

I did not know then what we know now, namely that 1988 was only the beginning of a process of deregulation, that the process reflected what was an epochal shift on a global scale, that even social democratic parties the world over would be overwhelmed by new liberal economic theories, that in the case of the Labour Party in Britain we would see major and explicit doctrinal revisionism, and that the onslaught against trade union and workers' rights would continue. In the year that I wrote the words above, Jacques Delors made a famous speech to the Trades Union Congress, which is credited with persuading a truculent British trade union movement to throw its weight behind Social Europe, the only safe harbour in turbulent times. ${ }^{9}$ This produced a number of positive outcomes in terms of social dialogue and social rights, building on the Community Charter of the Fundamental Rights of Workers. But this has proved to be only a brief respite, for now we are mourning the death of Social Europe, as the bug that bit Thatcher is now infecting the rest of the EU as well. ${ }^{10}$

Although others have since written about the decline of labour law in other jurisdictions, seven years after my piece was published Richard Mitchell took issue with me in Redefining Labour Law, a hugely influential collection of essays. ${ }^{11}$ Richard seemed particularly exercised by my claim that labour law as a force for good is tied to the principles of social democracy, ${ }^{12}$ and with the implication of the title of the piece (despite the question mark rather than an exclamation mark) that labour law was dead (though I had not suggested that a certificate to that effect had yet been issued). But despite Labour governments in a number of countries since, there has been little evidence that the patient is recovering or that the condition is not terminal as Harry Arthurs would have us believe. Since then we have seen the inexorable decline in trade union membership density and influence, along with the equally inexorable growth of the global corporation. ${ }^{13}$

9 See John Monks "The British Trade Unions and Europe" (2009) 15 Revue Française de Civilisation Britannique 153.

10 KD Ewing "The Death of Social Europe" (2015) 26 KLJ 76.

11 Richard Mitchell "Introduction: A New Scope and a New Task for Labour Law?" in Redefining Labour Law: New Perspectives on the Future of Teaching and Research (Centre for Employment and Labour Relations Law, University of Melbourne, Melbourne, 1995) at vii.

12 At vii.

13 Indeed, despite a trade union friendly government in the United Kingdom from 1997 to 2010 and despite trade union and worker friendly legislation, trade union membership and collective bargaining density continue to decline. 
What now seems to have been important was not the presence or otherwise of a Labour government, but the presence or otherwise of a government promoting a particular economic orthodoxy of which trade unions and labour law were conspicuously prominent parts. In other words, what is important is not the politics of the government of the day but the economics of the government of the day, with governments of both the right and the left promoting labour friendly policies in the Keynesian post-war era, and governments of both the right and the left promoting less labour friendly policies from the 1980s onwards. Nevertheless, Richard's concern was not only with the politics of labour law as I had set them out and as they have developed since. Rather, he was making the case that the focus of labour law should be with its ambit not its purpose, believing it to be the "decline or disappearance of law which serves certain purposes in regulating employment relationships or labour markets" which I was mourning (even though the patient was still performing limited functions). ${ }^{14}$

Richard reinforced the point by contending further that "with the decline of these [traditional] purposes, there are other laws, other policies and other institutions which impact upon or regulate those same, and other, relationships or markets". ${ }^{15}$ Accordingly, "[i]t is impossible ... to regard these other laws and so on as constituting something other than 'labour law"', ${ }^{16}$ writing later in the same piece that "there is no fundamental and unalterable purpose to labour law". ${ }^{17}$ Apart from criticising a particular understanding of the discipline, Richard proceeded to argue not only that this view was "mistaken", ${ }^{18}$ but that there was a need for a broader approach to the discipline to include questions that have been "marginalised or totally excluded". ${ }^{19}$ These included educational and tax concessions introduced for working mothers in Singapore, designed to improve the quality of skilled labour, which for that reason (its subject matter relating to workers and the labour market) would fall within the confines of labour law. ${ }^{20}$

\section{III}

At this point I have no difficulty with opening up the scope of labour law, consistently with the need for intellectual and practical coherence on the one hand, and the need not to lose sight of the core questions on the other. The danger of expanding the ambit is not just incoherence but a lack of focus on core questions. It is striking for example that in The Evolving Project of Labour Law, recently published, there is no chapter on collective bargaining, and not a single index reference to the

14 Mitchell, above n 11, at ix.

15 At ix.

16 At ix.

17 At xiv.

18 At viii.

19 At xiii.

20 At xii. 
question. ${ }^{21}$ Yet collective bargaining still regulates the working conditions of Australian workers directly and indirectly. Is labour law now to evolve without it? Is collective bargaining no longer a concern for labour lawyers? ${ }^{22}$ That said, it is hard to see why the borders of the discipline should be closed or that a wall should be used to keep some matters in and others out. But that said, I should make it clear that I do not think it is right to say that "there is no fundamental and unalterable purpose to labour law". 23

Here I think that labour market regulation law is not labour law any more than the law of master and servant law was labour law. It is not just a question of nomenclature: names, labels and titles are important as describing and revealing content and purpose. ${ }^{24}$ We no longer refer to our discipline as the law of master and servant, not only because the label does not reflect modern thinking, but also because the discipline does not share its values (though it may gradually be returning to them). Master and servant law - a species of the law of persons - is not the same as labour law, even though both occupy the same terrain. We need only to look at the values of the former to understand that they are not the values of the latter. Taking an 18th century text on Scots Law by way of example, we find that the law of master and servant had its origins in Roman Law, by which "servants ... were the property of their masters, and might be bought and sold as their goods; so that they were considered as subjects of commerce rather than as persons". ${ }^{25}$

Even as late as the 18th century, servants were "either necessary or voluntary", and if the former "the law obliges [them] to work". ${ }^{26}$ Erskine - the famous Scots lawyer - identified three categories of necessary labour, including "labourers, workmen or servants" who should they "refuse to serve at the rates fixed by the justices of the peace, the justices may compel them to it, by imprisonment, or farther imprisonment at their discretion". ${ }^{27}$ Erskine refers also to the "colliers, coal-bearers, salters, and other workmen necessary for the carrying on of collieries and salt-works", who "by the law itself,

21 John Howe, Anna Chapman and Ingrid Landau (eds) The Evolving Project of Labour Law: Foundations, Development and Future Research Directions (The Federation Press, Sydney, 2017). The omission is all the more striking for the fact that there is detailed legislation on the question in Australia as elsewhere.

22 Compare Alan Bogg and Tonia Novitz (eds) Voices at Work: Continuity and Change in the Common Law World (Oxford University Press, Oxford, 2014) which addresses contemporary concerns about collective bargaining structures and the role of labour law in making the process more effective.

23 Mitchell, above n 11, at xiv.

24 See Frank Tillyard Industrial Law (A and C Black, London, 1916).

25 John Erskine An Institute of the Law of Scotland (James Badenach Nicolson (ed), Bell and Bradfute, Edinburgh, 1871) vol 1 at [60].

26 At [61].

27 At [61]. 
without any action, bound merely by their entering upon work, in a colliery or salt-manufactory, to the perpetual service thereof". ${ }^{28}$ It was subsequently explained that: ${ }^{29}$

... [this] species of slavery had always been recognised in Scotland, from the supposed necessity of the case, it being imagined that no person would voluntarily engage in such works, so that they could never be worked at all except by slave-labour.

According to More: ${ }^{30}$

This state of slavery the origin of which is hid in deep obscurity, had subsisted for a long period, and its abolition was strenuously resisted, on the ground already mentioned; but at length the owners of collieries and salt-works, finding them very unproductive under this system of slave labour, were induced to try the experiment of working them by free men; and the result has amply proved that free labour, when judiciously employed, and properly remunerated, is far more productive than slave labour.

This is about the control and discipline of workers, not their emancipation through what Ruth Dukes refers to as democracy, freedom and human dignity. ${ }^{31}$ In that sense the law of master and servant precedes labour law, and in the same way in my view the law of the labour market succeeds it. Indeed, the first concern with the focus on the labour market is that it confounds the very foundation principle of labour law, which is that labour is not a commodity, ${ }^{32}$ the principle of international law that albeit is in tatters in the year of the centenary of its expression in the International Labour Organization (ILO) Constitution. Although Richard Mitchell claims that it is not his intention to "espouse a free market order based on property and contract", ${ }^{33}$ by following the market the risk of this approach nevertheless is that it leaves labour lawyers without the tools to resist the process of commodification. And while reifying workers and embracing the language of commodification may be explicable in a Marxist critique of labour law, my sense is that "Wage Labour and Capital" is not

28 At [61].

29 John Schank More Lectures on the Law of Scotland (John McLaren (ed), Bell and Bradfute, Edinburgh, 1864) vol 1 at 124. Also, on the political struggle for emancipation, see R Page Arnot A History of the Scottish Miners (Allen and Unwin, London, 1955).

30 More, above n 29, at 124. In other words, it was economic rationalism rather than political ideas of liberty that emancipated the Scottish miners.

31 See also Ruth Dukes The Labour Constitution: The Enduring Idea of Labour Law (Oxford University Press, Oxford, 2014) at 207.

32 See Paul O'Higgins "'Labour is not a Commodity' - An Irish Contribution to International Labour Law" (1997) 26 ILJ 225.

33 Mitchell, above $n$ 11, at xiii-xiv. 
the starting point for most of the pupils of the law of the labour market school. ${ }^{34}$ The starting point is simply that labour law is what happens, not what should happen. ${ }^{35}$

Whether intended or not, the risk is thus that law is subordinate to the market rather than an instrument for its control: the lawyer and the scholar are simply following the market rather than seeking to contain it. On this basis labour law is an empty vessel into which we pour anything and everything we have collected on the law relating to employment. ${ }^{36}$ We study the disintegration of the standard form contract, the imposition of flexible working, as well as the evisceration of collective power and the processes by which that power is exercised. But we have no view as to the merits or otherwise of these developments, because the discipline is normatively agnostic, stripped of its ethical core to reflect what might be described as the ethical aimlessness of the labour market school. ${ }^{37}$ It should be made clear nevertheless that Richard was mindful of the ethical dimension, writing about "the establishment of certain fundamental social objectives, including shared employment, democratic principles and freedom at work". ${ }^{38}$ But it is equally unclear where these social objectives come from, or indeed how or why they are different from the values espoused by critics of the labour market school such as Ruth Dukes (democracy, freedom and human dignity). ${ }^{39}$

\section{IV}

I agree that the boundaries of the discipline are not and were never closed (though I would be hesitant in opening them as wide as Richard suggests), and I believe that labour law has an ethical core purpose as a progressive law marching together with progressive politics and progressive economics. That said, I take issue with the claim that the study of labour law has been defined by

34 Karl Marx Wage Labour and Capital (Neue Rheinische Zeitung, Cologne, 1849).

35 RJ Pleasure and PA Greenfield "From Servants to Workers: A Modern Law of Work in the United States" in Paula B Voos (ed) Industrial Relations Research Association Series: Proceedings of the Forty-Seventh Annual Meeting (Industrial Relations Research Association, Washington, 1995) 180 at 181, as cited in Mitchell, above n 11, at vii-viii, n 4.

36 This is most vividly expressed in Anthony O'Donnell "When Was 'Labour Law"' in John Howe, Anna Chapman and Ingrid Landau (eds) The Evolving Project of Labour Law: Foundations, Development and Future Research Directions (The Federation Press, Sydney, 2017) 60 at 67: those engaged in the shift to a law of the labour market are engaged in a "normatively agnostic enterprise". That is a bold position.

37 The term "ethical aimlessness" was widely used by Anthony Lester in his human rights critique of the common law. I do not think the common law is ethically aimless just ethically wrong and democratically illegitimate, but I adopt the phrase as relevant for the current discussion. See Anthony Lester "The Magnetism of the Human Rights Act 1998" (2002) 33 VUWLR 477.

38 Mitchell, above $\mathrm{n} 11$, at xiv.

39 For an assessment, see contributions by Emilios Christodoulidis and others in "Ruth Dukes, The Labour Constitution" (2018) 9 Jurisprudence 209 at 394-407 and 413-417. 
Kahn Freund's important article published in $1954 .{ }^{40}$ The normative core of the discipline is determined not by academics but by those who have engaged in political struggle for its soul: workers, trade unions, employers, politicians and civil servants, national and international. The struggle for labour law was progressive and dynamic albeit faltering and incomplete until the end of the 1970s, which can be marked as the beginning of a point of regression in a few countries which has since become global, so that it becomes increasingly inappropriate to speak or write about labour law as a discipline.

If we are looking to find that progressive ethical core we find it in the ILO's Declaration of Philadelphia, a document that has been brilliantly rescued from relative obscurity by Alain Supiot, ${ }^{41}$ as a result of which it is known to a much wider audience than a small group of specialists in international labour law. By the Declaration of Philadelphia, the international community undertook a solemn commitment towards the end of the Second World War with a view to attaining conditions in which it would be possible to ensure that "all human beings, irrespective of race, creed or sex, have the right to pursue both their material well-being and their spiritual development in conditions of freedom and dignity, of economic security and equal opportunity". ${ }^{42}$ There is no mention here of the labour or any other kind of market in a document which begins by repeating the core principle on which labour law stands, namely "labour is not a commodity", ${ }^{43}$ a highly symbolic and heavily pregnant principle that goes beyond the 18th century bondage of Scottish colliers and saltworkers referred to above, or the "modern" slavery with which we are now becoming familiar. ${ }^{44}$

Returning to Philadelphia, the nations of the world undertook the solemn obligation to further (not promote) programmes that will achieve: 45

(a) full employment and the raising of standards of living;

(b) the employment of workers in the occupations in which they can have the satisfaction of giving the fullest measure of their skill and attainments and make their greatest contribution to the common well-being;

40 O Kahn Freund "Legal Framework" in Allan Flanders and HA Clegg (eds) The System of Industrial Relations in Great Britain: Its History, Law and, Institutions (Basil Blackwell, Oxford, 1954) 42.

41 Alain Supiot The Spirit of Philadelphia: Social Justice vs. the Total Market (Verso, New York, 2012).

42 International Labour Organization, Declaration of Philadelphia 1944 at II(a).

43 At I(a)

44 Joint Standing Committee on Foreign Affairs, Defence and Trade Hidden in Plain Sight - An Inquiry into Establishing a Modern Slavery Act in Australia (Parliament of the Commonwealth of Australia, December 2017).

45 International Labour Organization, Declaration of Philadelphia at III(a)-(j). 
(c) the provision, as a means to the attainment of this end and under adequate guarantees for all concerned, of facilities for training and the transfer of labour, including migration for employment and settlement;

(d) policies in regard to wages and earnings, hours and other conditions of work calculated to ensure a just share of the fruits of progress to all, and a minimum living wage to all employed and in need of such protection;

(e) the effective recognition of the right of collective bargaining, the cooperation of management and labour in the continuous improvement of productive efficiency, and the collaboration of workers and employers in the preparation and application of social and economic measures;

(f) the extension of social security measures to provide a basic income to all in need of such protection and comprehensive medical care;

(g) adequate protection for the life and health of workers in all occupations;

(h) provision for child welfare and maternity protection;

(i) the provision of adequate nutrition, housing and facilities for recreation and culture;

(j) the assurance of equality of educational and vocational opportunity.

This goes way beyond the traditional core of labour law as taught in universities, but nevertheless makes clear that labour law is defined not by its boundaries but by its purpose. The purposes of labour law as defined by the foregoing are those purposes forged by political struggle by the pioneers of the first half of the 20th century: protection of workers from the market, workers' rights preceding the market; social justice in the sense that labour law is one of several instruments "to ensure a just share of the fruits of progress to all"; 46 and participation in the government of working conditions through cooperation, collective bargaining and collaboration. The values enshrined in that Declaration are not timeless but functional, though rightly celebrated even if their reach has atrophied. That atrophy is matched only by the frequency by which these values are proclaimed, as in the two subsequent ILO Declarations of 1998 and 2008 respectively. ${ }^{47}$ For present purposes it is the latter - the Declaration on Social Justice for a Fair Globalisation - which is the most interesting if not currently the most influential.

46 International Labour Organization, Declaration of Philadelphia at III(d).

47 International Labour Organization, Declaration on Fundamental Principles and Rights at Work 1998; and the International Labour Organization, Declaration on Social Justice and a Fair Globalization 2008. 
Expressed as a "landmark Declaration", and a "powerful reaffirmation of ILO values", expressing "the contemporary vision of the ILO's mandate in the era of globalization", ${ }^{48}$ at the heart of the Declaration on Social Justice for a Fair Globalization is the understanding of the need for a renewal of the commitment to: ${ }^{49}$

- the fundamental values of freedom, human dignity, social justice, security and nondiscrimination are essential for sustainable economic and social development and efficiency;

- $\quad$ social dialogue and the practice of tripartism between governments and the representative organizations of workers and employers within and across borders are now more relevant to achieving solutions and to building up social cohesion and the rule of law through, among other means, international labour standards;

- the importance of the employment relationship should be recognized as a means of providing legal protection to workers ...

The question for labour law and those concerned with its future is whether it is possible to realise these commitments, or whether they are simply a lament for an era that has long since passed, a question to which I now turn.

\section{$\boldsymbol{V}$}

It seems to me undeniable that labour law in the terms outlined above is passing, my concerns in 1988 greatly underestimating the nature of economic and political change, and also its global reach. These changes are now impacting on the EU, hitherto the last bastion of social democracy, with core institutional arrangements under intense pressure as a result of coordinated open market pressures to deregulate. From a European perspective, this is what labour market law looks like, whatever the protestations about its ideological neutrality. It means: ${ }^{50}$

- decentralising and reducing the coverage of collective bargaining;

- deregulating employment standards and removing statutory protections; and

- facilitating the commodification of labour by one-sided flexibility arrangements promoting the idea of labour on demand.

And from a European perspective the political consequences of the apparent eclipse of labour law are profound, with the disintegration of the discipline arguably both a cause and a symptom of destabilising political disintegration, of which "Brexit" is simply an institutional expression.

48 International Labour Organization Declaration on Social Justice for a Fair Globalisation, at 1.

49 At $7-8$.

50 See Alan Bogg and KD Ewing "A Tale of Two Documents: The Eclipse of the Social Democratic Constitution" in Eva Nanopoulos and Fotis Vergis (eds) The Crisis Behind the EuroCrisis: The EuroCrisis as a Multidimensional Systemic Crisis of the EU (Cambridge University Press, Cambridge, 2019) 317. 
In order to understand whether this can change it is necessary to understand why it is happening in the first place. One of the questions that Gordon and I were planning to explore was whether there is such a thing as an autonomous labour law that could be rescued, about which I am increasingly sceptical, whether that be in terms of autonomy of doctrine and process, ${ }^{51}$ or autonomy of discipline from other intellectual disciplines beyond law. I am not speaking for Gordon here but while I vacillate from one position to another, my view in relation to the latter is that labour law is no more than a product of a particular political and economic epoch which has passed. It is the means by which economic and political objectives are implemented and is informed by the political values it develops. There are those who have a bleak dystopian view of the future and predict as a result that this epoch cannot be recreated and that labour law as it was known to a generation is in decline and cannot be reclaimed. Harry Arthurs is the chief proponent of that view, given famously known to disarm an audience by asking whether they think it likely that labour will be able to recover past glories 20 years hence or whether matters will remain broadly the same. Or worse.

This is a beguiling question, informed by a rich but pessimistic account of the changing nature of work and the changing nature of workers. In a series of important lectures, ${ }^{52}$ Arthurs has skilfully highlighted a number of interlocking factors which include some of the following:

- Neo-liberalism and the global commitment to open markets rather than social markets, a development now well underway even in the EU, hitherto the last bastion of social democratic labour law.

- Globalisation which is not only underpinning the power of multinational corporations, with the desire of governments for investment on the one hand and the fear of corporate flight on the other.

- Privatisation and outsourcing which not only helps to strengthen corporate behemoths, but also encourages the reduction of wages and working conditions as firms compete for contracts on cost.

- Austerity in the period after the global financial crisis in 2008 which has reinforced the trend in some countries to lower taxes, lower investment in public services, and lower wages.

- Global supply chains as corporations not only move production offshore but do so by giving up any responsibility for the employment of workers in the production of their goods.

51 See Lord Wedderburn "Labour Law: From Here to Autonomy?" (1987) 16 ILJ 1. The debate has moved on: see Alan Bogg and others (eds) The Autonomy of Labour Law (Hart Publishing, Oxford, 2015).

52 See for example Harry W Arthurs "The Transformation of Work, the Disappearance of 'Workers' and the Future of Workplace Regulation" (St John's College, University of Oxford seminar, 26 November 2009). See also Harry W Arthurs "Labor Law as the Law of Economic Subordination and Resistance: A Thought Experiment" (2013) 34 Comp Labor Law and Pol'y Journal 585. 
- $\quad$ The marketisation of labour: despite the legal principle that labour is not a commodity we write about labour markets without embarrassment, workers are commodified like any other factor of production.

- The flexibility of labour markets, which has seen active deregulation by removing legal protection, as well as the passive deregulation of the labour market by failing to address regulatory loopholes. ${ }^{53}$

- The growth of new forms of unprotected or partially protected employment, as employers have exploited the regulatory space vacated by legislatures and courts, with the expansion of self-employment and employment agencies.

- $\quad$ The free movement of labour, which enables states and employers to import workers cheaply to perform jobs that cannot be offshored, notably though not exclusively in the service economy.

- $\quad$ The decline in the voice of organised labour, which is struggling to find an effective role in the new economy and which has been marginalised as a political voice by its declining relevance.

If this is not enough, Arthurs makes other points to ram the point home even more securely, including what he refers to as the "disappearance" of workers as a self-identifying group. ${ }^{54}$ Workers see themselves as consumers not producers, they have multiple identities beyond class which is a submerged identity, with these multiple identities a source of conflict rather than solidarity between workers. ${ }^{55}$ Indeed, not only do workers cease to identify collectively as workers, labour is no longer a constituency with moral claims or voice and agency that political parties need to take seriously. ${ }^{56}$ According to Arthurs this is reflected in the abolition of Labour departments and Labour ministers in government in many countries (though a Department of Labour exists in Canada) as the voice of workers at the highest level. ${ }^{57}$ The concern of government is with prices rather than wages, workers encouraged to believe that their interests are served by lower taxes and cheaper food. This prioritisation of consumers over workers is to be seen in and is a reason for free trade agreements. ${ }^{58}$

53 For example, by the use of "substitution clauses" that allow employers to deny the existence of a contract of personal service, though the courts are increasingly addressing the omission of the legislature.

54 Arthurs "The Transformation of Work, the Disappearance of 'Workers' and the Future of Workplace Regulation", above n 52, at 4 and 6-7.

55 At 4 and 6-7.

56 At 8.

57 At 8.

58 David Boaz "The Benefit of Free Trade is Not Exports, It's Lower Prices on Things We Want" (22 May 2015) Cato Institute <www.cato.org $>$. 
The latter agreements of course will be of great benefit to the corporate giants who now stalk the earth. Both inward investment and exports to foreign markets will place additional pressure on wages and working conditions, as a price for cheaper goods and services. This is recognised in free trade agreements which invariably include a fairly detailed labour chapter, as in the case of the now defunct Transatlantic Trade and Investment Partnership (TTIP) and the post-Trump Comprehensive and Progressive Agreement for Trans-Pacific Partnership (CPTTP). ${ }^{59}$ The inclusion of these chapters in these agreements is a clear acknowledgement of the threat of free trade to labour standards, even in the case of agreements between large and highly developed economies, such as the EU and the United States. What is notable however is the extent to which these rights are included at the lowest level possible as the citizen's rights as worker are sacrificed to the citizen's interest as consumer. We are talking here about a duty to respect the four ILO principles, ${ }^{60}$ along with appropriate standards on wages, working time and occupational safety, what is appropriate to be determined by national governments alone. ${ }^{61}$

\section{VI}

For lawyers, there is of course yet another dimension which is highlighted by free trade agreements. The commitment to labour standards in these agreements serves only to highlight the extent to which they are either (i) ignored, (ii) not fully complied with and (iii) continuing to be violated. This raises questions about the extent to which the neo-liberal counter-revolution is based on a repudiation of the rule of law, which of course would be surprising given that respect for the rule of law is one of the foundations of the neo-liberal case, and part of the basis of its critique of social

59 Comprehensive and Progressive Agreement for Trans-Pacific Partnership (opened for signature 8 March 2018, entered into force 30 December 2018). At the time of writing, the Comprehensive and Progressive Agreement for Trans-Pacific Partnership is yet to be ratified by New Zealand. For discussion, see Tham and Ewing, above n 6. See also Joo-Cheong Tham and KD Ewing "Trade Agreements and Australian Labour Law - Implications of the Death of the Transatlantic Partnership Agreement" in John Howe, Anna Chapman and Ingrid Landau (eds) The Evolving Project of Labour Law: Foundations, Development and Future Research Directions (The Federation Press, Sydney, 2017) 246.

60 See the International Labour Organization, Declaration on Fundamental Principles and Rights at Work 1998: freedom of association, abolition of forced labour, elimination of child labour and elimination of discrimination. These principles are based on the eight fundamental conventions of the International Labour Organization (ILO). Only three of the 11 parties of the CPTTP (Canada, Chile and Peru) have ratified all eight fundamental conventions, though Canada is the subject of constant complaints to the International Labour Organization (ILO) supervisory bodies over the years, with over 100 complaints to the ILO Freedom of Association Committee.

61 See Comprehensive and Progressive Agreement for the Trans-Pacific Partnership, above n 59, art 19.3(2): "[e]ach Party shall adopt and maintain statutes and regulations, and practices thereunder, governing acceptable conditions of work with respect to minimum wages, hours of work, and occupational safety and health". It is further provided at $\mathrm{n} 5$ that "[f]or greater certainty, this obligation relates to the establishment by a Party in its statutes, regulations and practices thereunder, of acceptable conditions of work as determined by that Party". I am grateful to Joo-Cheong Tham for bringing this footnote to my attention. 
democracy. ${ }^{62}$ Claims that the rule of law is a casualty of neo-liberalism nevertheless require some justification, not least because it is an easy charge to make, as a result of the slippery and indeterminate nature of the concept itself, with scholars making a variety of grossly inflated and unconvincing claims as to its content. ${ }^{63}$ For present purposes, however, it is enough to say that the rule of law means that the government must comply with its legal obligations, whether these obligations are imposed by national law or arise by virtue of international law. ${ }^{64}$

Free trade agreements such as СРТPP give visibility to the fact that many countries are in breach of international labour conventions by which they are bound, and consequently in breach of the fresh undertakings to comply with international labour principles in the free trade agreements which they so lightly undertake. They undertake them lightly in the sense that there is no intention of compliance, signatories confident in the knowledge that they will not be under any pressure to comply. As JooCheong Tham and I pointed out in evidence recently submitted to a Senate inquiry in Australia on which the following account draws, almost everyone is in breach in what is a framework of mutually assured non-compliance. ${ }^{65}$ Take Australia, and take ILO Conventions 87 and 98 by way of illustration, both of which Australia has ratified. Here it is notable that the Australia-US Free Trade Agreement signed in 1995 contains similar obligations to CPTPP in respect of ILO core standards. Yet that did not deter the Howard Government from introducing the Workplace Relations Amendment (Work Choices) Act 2005 (Cth), which was found by the ILO supervisory bodies comprehensively to have breached these conventions and principles. ${ }^{6}$

It is true that we have since seen the enactment of the Fair Work Act 2009 (Cth) under the Rudd Government. It remains the case, nevertheless, that the ILO supervisory bodies are unpersuaded that

62 FA Hayek The Road to Serfdom (Routledge Press, Abingdon-on-Thames (UK), 1944) at 54: "[n]othing distinguishes more clearly conditions in a free country from those in a country under arbitrary government than the observance in the former of the great principles known as the Rule of Law". See also FA Hayek The Constitution of Liberty (University of Chicago Press, Chicago, 1960) at ch 18 on trade union legal freedoms as a violation of these "great principles".

63 For a discussion, see Jeffrey Goldsworthy "Legislative Sovereignty and the Rule of Law" in Tom Campbell, KD Ewing and Adam Tomkins (eds) Sceptical Essays on Human Rights (Oxford University Press, Oxford, 2001) 61.

64 See Lord Bingham "The Rule of Law" (2007) 66 CLJ 67.

65 See Joo-Cheong Tham and KD Ewing "Submission to the inquiry of the Senate Foreign Affairs, Defence and Trade References Committee into the proposed Comprehensive Progressive Trans-Pacific Partnership". I am grateful to Joo-Cheong Tham for permission to draw on this material here.

66 On the Committee of Experts response to which, see International Labour Organization "Observation (CEACR) - adopted 1998, published 87th ILC session (1999)" <www.ilo.org>. 
Australia meets its obligations under ILO Conventions 87 and 98. After a review of Australian labour law in 2016, the Committee of Experts concluded in relation to Convention 87:67

The Committee once again requests the Government to take all appropriate measures, in the light of its previous comments and in consultation with the social partners, to review the abovementioned provisions of the Fair Work Act, the Competition and Consumer Act and the Crimes Act with a view to bringing them into full conformity with the Convention. In the meantime, the Committee requests the Government to provide detailed information on the application of these provisions in practice.

The Committee also considered concerns raised by the Australian Council of Trade Unions in relation to Convention 98. It will be noted that in the case of both Conventions 87 and 98 the Committee is renewing criticism that has been made on several occasions previously, criticism to which Australian governments have failed to respond. Indeed, there have been Observations from the Committee of Experts relating to Australia on at least 13 occasions since 1996 in connection with ILO Convention 87 and on at least 15 occasions in connection with ILO Convention 98.

The issues raised by these observations are important, and include restrictions on the right to bargain collectively, as well as the right to strike. Some of these concerns have also been ventilated before the ILO Freedom of Association Committee, most recently relating to the impact of New South Wales legislation on the collective bargaining rights of public sector workers. ${ }^{68}$ But rather than respond to these concerns, we find fresh proposals that in the view of the Commonwealth Parliament's Joint Committee on Human Rights will lead to further violations of fundamental labour standards. These include the provisions of the Fair Work (Registered Organisations) Amendment (Ensuring Integrity) Bill 2017 (Cth), which the Committee has found either (i) "likely to be", or (ii) "may be" inconsistent with Australia's freedom of association obligations. ${ }^{69}$ The former included those relating to the disqualification of individuals from holding union office and the public interest test for trade union amalgamations, while the latter included the placing of unions into administration. ${ }^{70}$

67 See International Labour Organization "Observation (CEACR) - adopted 2016, published 106th ILC session (2017)" <www.ilo.org>. See also "Other comments on CO87" on this webpage for issues raised about Australia's compliance with ILO Convention 87 since 1995.

68 International Labour Organization "Case No 3118 (Australia) - Complaint date: 04-MAR-15" $<$ www.ilo.org $>$.

69 See for example Parliamentary Joint Committee on Human Rights Human Rights Scrutiny Report (Report 12 of 2017, 28 November 2017) at [2.107] and [2.142]. The Parliamentary Joint Committee on Human Rights is required by its mandate to examine Bills and other instruments by reference to a number of international human rights instruments, instruments which the Committee acknowledges are informed by ILO treaties, notably Conventions 87 and 98. This would be particularly true of the International Covenant on Economic, Social and Cultural Rights.

70 At 113; and Parliamentary Committee on Human Rights Human Rights Scrutiny Report (Report 2 of 2018 , 13 February 2018). 
But even amongst CPTPP states, Australia is not alone in being in breach of freedom of association conventions:

- Apart from Australia five of the other ten parties to the CPTPP have ratified ILO Convention 87, the five in question being Canada, Chile, Japan, Mexico and Peru. The Committee of Experts has raised concerns of different levels of intensity in recent years in relation to each of these countries, though so far as Canada is concerned in 2016 the Committee was able to report its satisfaction about legislative changes following a Supreme Court of Canada decision that various strike restrictions in Saskatchewan were unconstitutional. ${ }^{71}$ But issues remain in other Canadian provinces, and serious issues were also identified in Chile (2015), Japan (2016), Mexico (2016) and Peru (2014). ${ }^{72}$

- Apart from Australia seven of the other ten parties to the CPTTP have ratified ILO Convention 98, the seven in question being Canada, Chile, Japan, Malaysia, New Zealand, Peru and Singapore. Again, the Committee of Experts has raised concerns in the form of Observations or Direct Requests relating to matters of different levels of intensity about Chile (2016), Japan (2017), Malaysia (2017), New Zealand (2017) and Peru (2015), across a wide range of issues. The exclusion of Singapore seems unconvincing and Canada is excepted because it only recently ratified Convention 98 and has yet to be the subject of meaningful scrutiny, though the Supreme Court jurisprudence may help. ${ }^{73}$

Freedom of association guarantees voluntarily undertaken are honoured in the breach it seems, the failure of legality not confined to the Trans-Pacific region. ${ }^{74}$ Nor as a result is the globalisation of illegality and disrespect for the rule of law. ${ }^{75}$

71 Saskatchewan Federation of Labour v Saskatchewan, above $\mathrm{n} 5$.

72 So, in relation to ILO Convention 87, all parties to the CPTTP have either not ratified it, or face serious questions about the extent of their compliance

73 Despite the decision on the right to strike in Saskatchewan, above n 5, a much overlooked feature of the decision is the acceptance by the Supreme Court of Canada of high statutory thresholds for certification of a collective bargaining agent, raising questions of compatibility with ILO Convention 98, art 4 (duty to promote collective bargaining).

74 On the failure to comply with ILO and Council of Europe freedom of association obligations by an '"overwhelming majority"' of the EU's 28 member states, see Keith D Ewing and John Hendy "The Eclipse of the Rule of Law: Trade Union Rights and the EU" (2015) 4 Revista Derecho Social y Empresa 80. For an altogether brilliant account of the collapse of legality in Greece as a result of international pressure, see Ioannis Katsaroumpas "De-Constitutionalising Collective Labour Rights: The Case of Greece" (2017) 47 ILJ 465.

75 There are other rule of law issues relating to free trade agreements, not least the dispute resolution procedures under investor-state dispute settlement (ISDS), which enable investors to challenge legislation in host countries in secret arbitral forums. See Keith Ewing and John Hendy "TTIP and the Rule of Law: a response to Jude Kirton-Darling MEP" (11 June 2015) Left Futures < www.leftfutures.org>. The point was picked up by the Labour Party front bench spokesman the Hon Barry Gardiner during debates on the EU-Canada Comprehensive Economic and Trade Agreement, where he said that "[i]t is ironic that, just as we are told we 


\section{VII}

It is hard not to share Arthurs' pessimism, and indeed if anything he understates the scale of the challenge. In these circumstances is there any reason to believe that the patient can be resuscitated? Or is this an inevitable and permanent state of affairs? Imagine you were in an audience in London in 1927. The Labour movement was at the nadir of its fortune. Membership had plummeted in a period of austerity, the trade unions had been humiliated by the General Strike of 1926 and now faced punishing legislative restraints on industrial and political activity, ${ }^{76}$ the first minority Labour Government had lasted barely a year before being defeated on a confidence vote in 1924, ${ }^{77}$ and we stood on the threshold of the second Labour government (1929-1931) which would see the government split leaving the Parliamentary Labour Party leaderless and with a rump of MPs in 1934. Who then in that audience would have predicted that only 20 years later we would be in the process of nationalising the commanding heights of the economy, that we would have a socialised National Health Service free at the point of use, and collective bargaining density of 86 per cent? ${ }^{78}$

What this reveals is that the law regulating workers and trade unions - like many other things is cyclical and not inevitable or permanent. ${ }^{79}$ Indeed, since the 1850 s it is possible to identify four cycles of regulation which can be described broadly as:

- Liberal economic based on common law doctrines based on little worker protection and the illegality of trade unions and their activities.

- Social liberal based on basic levels of statutory protection for workers and the emancipation of trade unions from various common law restraints.

- Social democratic based on the regulation of working conditions through collective bargaining as an instrument of worker engagement and protection.

need to leave the EU to regain control of our laws and how they are interpreted in the courts, Parliament's ability to legislate in the public interest is being curtailed by negative lists and regulatory chill and by the establishment of a supranational courts system where foreign businesses are given superior rights to our own domestic companies and can tell our Government what they can and cannot do if they are not to sue us for taking sensible public policy decisions to protect the public against new and emerging dangers": (26 June 2018) 643 GBPD HC 2871. Needless to say these objections were waived aside and Parliament voted to approve the agreement.

76 Trade Disputes and Trade Unions Act 1927 (UK), repealed by the third Labour Government in 1946 by an Act with the same short title.

77 See Richard W Lyman The First Labour Government 1924 (Chapman and Hall, London, 1957).

78 On the greatly enhanced role of trade unions in the post-war government, see Samuel H Beer Modern British Politics (Faber and Faber, London, 1965).

79 See KD Ewing "Australian and British Labour Law - Differences in Form or Substance?" (1998) 11 AJLL 44. 
- $\quad$ Neo-liberal economic based on the deregulation of employment protection legislation and the dismantling of collective bargaining structures. ${ }^{80}$

We will inevitably see the continued evolution of worker and trade union rights, though no one can be certain of the direction of travel.

What is notable, however, is that the change from one epoch to another was preceded by a period of great political upheaval, economic crisis, and/or major geo-political event such as a military conflict or revolution. What is also notable is that such changes are associated with a change in economic policy, as in the 1930s when there was a significant shift to sectoral regulation of employment conditions in what were then the leading liberal democracies. ${ }^{81}$ What is notable further is that such change was not only introduced simultaneously in more than one country, but that the presumed ideology of the government of the day was irrelevant. So while it was Roosevelt who pioneered the National Industrial Recovery Act of 1933 with its ill-fated and short-lived industry codes, ${ }^{82}$ it was the Liberal Unionist Minister of Labour in a Tory-led Coalition Government who announced to the British House of Commons five years later that it was the policy of the government to promote collective bargaining, ${ }^{83}$ the Prime Minister at the time (Stanley Baldwin) having previously led the campaign for statutory reparations against the trade unions after the General Strike in 1926.

To be pessimistic about whether labour law can be revived is not only to be remarkably pessimistic about the capacity of the political process to deliver change, but also correspondingly optimistic about current international and national economic stability. That said, it seems to me to be a necessary precondition to the revival of labour law that there should be a major refocus of economic policy of the kind that was seen in the 1930s with institutions that remained in place until the 1980s, which in the British case were sustained by governments of both parties and strengthened in the 1970s (which is not to deny that the arrangements were constantly contested). ${ }^{84}$ This is because the experience of the last 40 years has revealed clearly that labour law is an instrument of economic policy, and that to

80 Note the need for caution in the lazy use of neo-liberalism: Alan Bogg "New Labour, Trade Unions and the Liberal State" (2009) 20 KLJ 403. See subsequently, Alan Bogg "Beyond Neo-Liberalism: The Trade Union Act 2016 and the Authoritarian State" (2016) 45 ILJ 299.

81 KD Ewing "The EU, the USA, and TTIP - Collective Bargaining and the Emerging 'Transnational Labor Relations Act"' (2016) 117 Theory \& Struggle 16. For different origins of modern labour law, see Dukes, above $\mathrm{n} 31$.

82 ALA Schechter Poultry Corp v United States 295 US 495 (1935).

83 (11 May 1938) 335 GBPD HC 1621.

84 Most notably in the courts, as in Rookes v Barnard [1964] AC 1129 (HL). See Roger Welch "Rookes v Barnard and the Re-emergence of Judicial Intervention in Industrial Disputes" (paper presented at 1906-2006 From the Trade Disputes Act to a Trade Union Freedom Bill conference, Liverpool, 10 May 2006). 
restore labour law as discussed earlier in this article is to restore a different kind of economics. ${ }^{85}$ To restore labour law means the need first to restore the economic and political conditions that would make such labour law not only sustainable but also necessary. ${ }^{86}$

That would require a government committed to the two core provisions of the Declaration of Philadelphia, notably: ${ }^{87}$

(a) policies in regard to wages and earnings, hours and other conditions of work calculated to ensure a just share of the fruits of progress to all, and a minimum living wage to all employed and in need of such protection;

(b) the effective recognition of the right of collective bargaining, the cooperation of management and labour in the continuous improvement of productive efficiency, and the collaboration of workers and employers in the preparation and application of social and economic measures.

This is not to say that it is not possible to secure changes to ameliorate the worst effects of an open market economy, whether by legislation or litigation. But the potential is limited with experience showing clearly enough that a progressive labour law marches hand in hand with progressive economics and progressive politics.

\section{VIII}

I have been concerned in this article to revisit old arguments about the death of labour law, which seem to me to be even more pertinent some 30 years later. For this purpose, I have re-examined claims by Richard Mitchell that such claims are mistaken, and that while we may be mourning the death of a particular species of labour law, the discipline has metamorphosed with a new focus as the law of the labour market. In my view the latter is not labour law as that genus developed in the middle of the 20th century, but a different genus that has emerged for the different purposes of a different political economy. If the latter dies so does the legal discipline that was both created to sustain it and sustained

85 This is not to say that the case for labour law can be made on the basis of economic efficiency, efficiency here begging as many questions as the scope and function of labour law. But it is to suggest that labour law cannot be separated from economic policy, and labour law is simply a tool of economics - a way of making things happen, an instrument of economic policy. There have been two great epochal changes in labour law in the 20th century both of which had global implications. The first of these was in the early 1930s in response to the then global financial crisis which saw steps in the United States and elsewhere to create a labour law for a new era in which incomes would be increased and wealth would be redistributed. This would be done principally by state sponsored collective bargaining and intensive regulation, which in the United States foundered on a constitution which had been drafted in a different century to address different concerns, the political liberalism of the constitution incompatible with the economic radicalism of the New Deal.

86 Necessary in the sense that sectoral collective bargaining is an efficient way of raising wages and promoting income equality.

87 International Labour Organization, Declaration of Philadelphia at III(d) and (e). 
by it. I do not disagree with Richard's claim that the traditional boundaries of labour law were sometimes too narrow. However, while this is a criticism that might be made of some pioneering scholars he identifies, it is not a criticism that could fairly be made of those whose struggles created iconic texts such as the ILO's Declaration of Philadelphia.

The purpose of revisiting that old argument is to consider whether labour law as outlined can be resurrected, having regard to the recent work of Harry Arthurs which provides a glimpse of an unremittingly bleak outlook and an equally unremittingly bleak future for those of us who like Gordon Anderson were schooled in an earlier era. I agree with much of Harry Arthurs' diagnosis which if anything is understated, the scale of the decline underpinned further by the disregard for legality. But I disagree with the pessimism of the prognosis, which fails to address the dynamic nature of labour law tied closely to changing economic and political orthodoxies. There is no inevitability about current arrangements, though it is true that while change is constant it does not follow that any future epochal change will be in a progressive direction. That said, we have vacillated between the social and the liberal for the best part of 200 years and there is no reason to think that we will not continue to do so, giving purpose to the contemporary political struggles of the global labour movement. 